\title{
A Model of Development Maritime Tourism Competitiveness in Nikoi Island, Riau Islands Province
}

\author{
I Dewa Gde Sugihamretha ${ }^{1}$ \\ Ministry of National Development Planning/BAPPENAS
}

\begin{abstract}
This study aims to explain the factors and models to develop the competitiveness of marine tourism destinations in Nikoi Island, Bintan Regency, Riau Islands Province by using a qualitative approach (descriptive method). Data and information were generated through in-depth interviews, Focus Group Discussion (FGD), and literature studies which were then analyzed using the Porter Value Chain framework (1985). The richness and uniqueness of natural resources that can offer beauty and experience for travelers are basic capital for the development of marine tourism in Nikoi Island. Investors play a central role which starts from planning, construction design to management and continuous business improvement. A large percentage of Bintan's PAD comes from their tourism sector which includes Nikoi island. The development of Nikoi Island as a tourist destination can be used as a model to develop inclusive and sustainable marine tourism in thousands of other small islands owned by Indonesia with private sector acting as the main investor. However, during implementation in the field, private sector cannot stand alone. They must be able to cooperate with the Government (both at Central and Regional level) and other related stakeholders. In national midterm plan 2020 - 2024, the development of tourism in small islands can be seen as a breakthrough that forms new economic growth centers.
\end{abstract}

Keywords: Competitiveness, Tourism, Maritime, Islands Development, Nikoi Island, Riau Islands.

\footnotetext{
${ }^{1}$ I Dewa Gde Sugihamretha is a Principal Planner at Ministry of National Development Planning/Bappenas RI. Email address: gde@bappenas.go.id
} 


\section{Model Pengembangan Daya Saing Wisata Bahari di Pulau Nikoi, Propinsi Kepulauan Riau}

\section{Dewa Gde Sugihamretha}

\section{Pendahuluan}

\subsection{Latar Belakang}

Peran dan prospek industri pariwisata Indonesia cenderung tumbuh setiap tahun. Jumlah wisatawan mancanegara naik dari sekitar tujuh juta lebih wisatawan (2011) menjadi sekitar dua belas juta lebih (2016). Devisa yang masuk meningkat dari 8.554 juta dolar AS (2011) menjadi 12.440 juta dolar AS (2016). Kinerja serupa juga terjadi untuk wisatawan nusantara (wisnus). Jumlah perjalanan wisnus mencapai 256,4 juta (2015), naik 2,06 persen dibandingkan tahun 2014 (251,2 juta). Jumlah pengeluaran konsumsi wisnus pada 2015 mencapai Rp 224,69 trilyun atau rata-rata Rp 876,3 ribu per perjalanan. Pada level global, industri pariwisata diprediksi menjadi motor penggerak sosial dan ekonomi dunia. Perjalanan turis internasional tumbuh 4\% pada 2016 dibandingkan 2015, mencapai 1.235 juta perjalanan dan menghasilkan total devisa US\$ 1.5 trilliun di sektor pariwisata. Pada tahun 2030, UNWTO memperkirakan perjalanan turis internasional mencapai 1,8 miliar perjalanan (UNWTO, 2017).

Sebagai Negara kepulauan, Indonesia berpotensi besar mengembangkan wisata bahari, antara lain dengan mengoptimalkan pemanfaatan Pulau-Pulau Kecil (PPK). Dari 17.100 pulau, baru 13.466 pulau yang telah diberi nama, sekitar 1.900 diantaranya termasuk kategori PPK. Suharsono, Soegiarto dan Polunin dalam Dahuri (1998) menjelaskan PPK memiliki flora dan fauna khas dan tidak dimiliki negara lain. Kekayaan biota laut Indonesia mencapai 80 genus dan 590 spesies terumbu karang; 2.500 spesies moluska, 1.512 spesies krustasea, 850 spesies sponge, 2.334 spesies ikan laut, 30 spesies mamalia laut, dan 38 spesies reptilia.

Terdiri atas sekitar 241 pulau, Kabupaten Bintan Propinsi Kepulauan Riau adalah salah satu Pemerintah Kabupaten yang menetapkan sektor pariwisata sebagai prioritas untuk mempercepat pembangunan di kawasan tersebut. Dari 241 pulau tersebut, sekitar 50 pulau dihuni penduduk dan masih ada sekitar 190 lebih yang tidak berpenduduk. Sebagian besar Pendapatan Asli Daerah (PAD) Kabupaten Bintan saat ini ditopang sektor pariwisata, nilainya Rp 92,79 miliyar dari total PAD Bintan sekitar Rp167,5 miliyar (55,5\%). PAD industri pariwisata tersebut diperoleh dari pajak hotel, restoran, hiburan, retribusi, dan Pajak Bumi Bangunan terutama di kawasan pariwisata free zone Lagoi (Muf, 2015).

Pulau-Pulau di Kabupaten Bintan tidak hanya menawarkan panorama pantai yang indah namun juga pemandangan bawah laut menawan. Dari ratusan Pulau yang ada, baru enam Pulau yang telah dikelola untuk tujuan wisata bahari secara profesional, diantaranya Pulau Nikoi - sebuah pulau yang dikelola investor asing, berjarak lima kilometer dari pantai timur Pulau Bintan. Dengan luas 16,5 hektar, Pulau Nikoi terdiri atas 15 resor dan telah berkembang menjadi tujuan liburan butik para wisatawan dari seluruh dunia. Tiap bulan rata-rata manajemen Pulau Nikoi menyetor pajak daerah sekitar 400 juta rupiah dari kegiatan mengelola wisatan bahari di pulau tersebut. 


\subsection{Tujuan Kajian}

Pembangunan wisata bahari PPK memerlukan pendekatan dalam perspektif sistem untuk memahami setiap aspek sumberdaya dan peran para pelaku yang terlibat dalam kawasan tersebut dengan baik. Riset pengembangan daya saing wisata bahari di Pulau Nikoi, Kabupaten Bintan, Propinsi Kepulauan Riau ini memiliki dua tujuan. Pertama, menjelaskan faktor-faktor yang mempengaruhi daya saing Pulau Nikoi sebagai salah satu tujuan wisata bahari. Kedua, mendeskripsikan model pengembangan daya saing Pulau Nikoi sebagai kawasan tujuan wisata bahari dengan menggunakan pendekatan konsep rantai nilai.

\section{Tinjauan Literatur}

\subsection{Wisata Bahari}

Peraturan Pemerintah (PP) Republik Indonesia No. 50 tahun 2011 tentang Rencana Induk Pembangunan Kepariwisataan Nasional tahun 2010 - 2025 telah menetapkan pengembangan pariwisata di Indonesia dilaksanakan dengan mengoptimalkan potensi daya tarik sumberdaya alam di Indoneia. Praktik wisata tersebut dibagi menjadi tiga katagori, yaitu: 1) Wisata bahari (marine tourism), 2) Ekoturism (ecotourism), dan 3) Wisata petualangan (adventure tourism).

Wisata bahari memanfaatkan daya tarik wisata alam yang berbasis potensi keanekaragaman dan keunikan lingkungan alam di wilayah perairan laut. Ecotourism adalah daya tarik wisata alam yang berbasis potensi keanekaragaman dan keunikan lingkungan alam di wilayah daratan. Sedangkan wisata petualangan memanfaatkan daya tarik wisata alam yang berbasis potensi keanekaragaman dan keunikan lingkungan alam.

Wisata bahari dapat dibagi menjadi tiga kategori. Pertama, wisata pantai dengan menawarkan keindahan pantai (coastal zone) untuk kegiatan sun bathing, sightseeing, olah raga pantai, dan atraksi manarik lainnya. Kedua, wisata keindahan bentang laut (sea zone) yang terbentang dari perairan di sekitar pesisir pantai maupun lepas pantai, menjangkau jarak tertentu. Kegiatan wisata bentang laut antara lain sailing, yachting, cruising dan lainlain, seperti di Kepulauan Seribu. Ketiga, wisata bawah laut (under water zone), misalnya wisata menyelam (diving) di Taman Laut Bunaken, Taman Laut Wakatobi, Raja Ampat, dan sebagainya.

\subsection{Karakteristik Pulau-Pulau Kecil (PPK)}

Pulau kecil adalah pulau yang secara fisik berukuran kecil, berkarakteristik khas, dan terpisah dari pulau induknya sehingga bersifat insular. Bila terjadi pasang tertinggi pulau kecil tidak tertutupi oleh air pasang (Dahuri, 1998, dan Bengen, 2001). Beberapa ahli mendefinisikan luas pulau kecil berkisar antara 100 sampai dengan $10.000 \mathrm{~km}^{2}$ (UNESCO dalam Sugandhy, 1999; Falkland, 1995; UNESCO dalam Bengen, 2006). Berdasarkan pasal 1 UU No 27 tahun 2007 tentang Pengelolaan Wilayah Pesisir dan Pulau Pulau Kecil, pulau kecil adalah pulau dengan luas lebih kecil atau sama dengan $2000 \mathrm{~km}^{2}$ (dua ribu kilometer persegi) beserta kesatuan ekosistemnya.

Pulau-Pulau Kecil memiliki kepekaan tinggi terhadap perubahan dan dinamika aspek-aspek budaya dan interaksi sosial dari eksternal (Stratford, 2003). Royle (2001) menjelaskan ada dua faktor yang mempengaruhi pengembangan PPK untuk daerah tujuan wisata yaitu faktor keterisolasian (isolation) dan keterbatasan (boundedness). Keterisolasian 
memberikan nilai kepetualangan sedangkan keterbatasan memberikan nilai-nilai atau terkait dengan nilai-nilai tantangan.

Karakteristik khusus PPK merupakan tantangan tersendiri dalam upaya pembangunan kawasan PPK sebagai tujuan wisata yang berdaya saing tinggi. Kendala utama terkait aksesibilitas yang rendah, biaya pembangunan yang tinggi dan ketersediaan sumberdaya manusia (kuantitas dan kualitas) yang terbatas. Kondisi tersebut menyebabkan minimnya ketersediaan infrastruktur dasar, seperti fasilitas pendidikan, kesehatan, listrik, komunikasi (telepon, televisi, radio), air bersih, dan berbagai fasilitas pendukung pengembangan ekonomi penduduk lainnya. Dampak kondisi tersebut adalah tingginya angka kemiskinan dan degradasi lingkungan di pulau-pulau kecil. Aktivitas IUU (illegal, unreported, and unregulated) dalam pengelolaan perikanan mendorong terjadinya kerusakan terumbu karang dan penebangan liar mangrove. Kondisi ini dapat mengancam eksistensi pulau dan ketahanan masyarakat di pulau-pulau kecil tersebut (Agus Dermawan dan Arif Miftahul Aziz, 2012).

\subsection{Daya Saing Pariwisata}

Tonggak penting kajian daya saing (competitive advantage) dimulai dengan karya Porter (1990) tentang konsep daya saing negara-negara. Ia mendefinisikan daya saing nasional sebagai hasil kemampuan suatu bangsa untuk mencapai atau mempertahankan posisi menguntungkan di antara negara-negara lain di sektor industri utama (Tsai, Song, dan Wong, 2009). Organisasi untuk Kerjasama Ekonomi dan Pembangunan (OECD) dalam Tsai, Song, dan Wong (2009) mendefinisikan daya saing sebagai "tingkat di mana suatu negara dapat, di bawah kondisi pasar yang bebas dan adil, menghasilkan barang dan jasa yang memenuhi kebutuhan pasar internasional, sekaligus menjaga dan memperluas pendapatan riil rakyatnya dalam jangka panjang. Papadakis (1994) dalam Tsai, Song, dan Wong (2009) menguraikan daya saing suatu negara dapat diukur dengan akumulasi daya saing perusahaan yang beroperasi di dalam batas-batasnya.

Isu daya saing tujuan atau destinasi pariwisata semakin penting, terutama untuk negara dan kawasan yang sangat bergantung pada pariwisata (Gooroochurn \& Sugiyarto, 2005). Tujuan wisata dianggap kompetitif jika dapat menarik dan memuaskan calon wisatawan. Daya saing suatu tujuan wisata secara langsung mempengaruhi penerimaan pariwisata dalam hal jumlah dan pengeluaran pengunjung. Selain itu, secara tidak langsung daya saing tujuan wisata mempengaruhi kinerja bisnis yang terkait dengan pariwisata, seperti hotel dan industri ritel di tempat tujuan tersebut. Seperti yang ditunjukkan Cizmar dan Weber (2000), pilihan tujuan wisata tetap menjadi salah satu keputusan pertama dan terpenting yang dibuat oleh wisatawan. Keputusan ini sebagian besar juga dipengaruhi oleh sejumlah faktor eksternal, seperti citra negara, aksesibilitas, daya tarik, keamanan, dan lainlain.

\subsection{Konsep Rantai Nilai}

Gagasan rantai nilai didasarkan pada pandangan proses organisasi. Gagasan tersebut melihat organisasi manufaktur (atau layanan) sebagai sebuah sistem, terdiri atas masing-masing sub-sistem dengan masukan, proses transformasi, dan keluaran; melibatkan perolehan dan konsumsi sumber daya (uang, tenaga kerja, bahan, peralatan, bangunan, tanah, 
administrasi dan manajemen). Aktivitas rantai nilai dilakukan untuk menentukan biaya dan mempengaruhi keuntungan. Sebagian besar organisasi melibatkan ratusan bahkan ribuan aktivitas untuk mengubah input menjadi keluaran. Kegiatan ini dapat diklasifikasikan secara umum sebagai kegiatan utama atau dukungan yang harus dilakukan oleh semua pelaku bisnis dalam beberapa bentuk. Menurut Porter (1990) rantai nilai merupakan cara sistematik untuk menganalisis sumber keunggulan bersaing dengan memeriksa semua aktivitas yang dilakukan dan bagaimana semua aktivitas itu berinteraksi satu sama lainnya. Interaksi antar satu komponen dengan yang lain akan memberikan dampak pada nilai yang teraktualisasikan atau terbagikan pada pelanggan.

Rantai nilai adalah suatu konsep untuk memberikan sesuatu kebermaknaan pada konsumen. Istilah rantai nilai mengacu pada serangkaian kegiatan yang diperlukan untuk menghadirkan suatu produk (atau jasa) dimulai dari tahap konseptual, dilanjutkan dengan beberapa tahap produksi, hingga pengiriman ke konsumen akhir dan pemusnahan setelah penggunaannya (Kaplinsky 1999; Kaplinsky dan Morris 2001). Rantai nilai terbentuk ketika semua pelaku dalam rantai tersebut bekerja sedemikian rupa sehingga memaksimalkan terbentuknya nilai sepanjang rantai tersebut.

Porter (1985) menggunakan kerangka rantai nilai untuk mengkaji bagaimana suatu perusahaan seharusnya memposisikan dirinya di pasar serta di dalam hubungan mereka dengan para pemasok, pembeli, dan pesaing. Menurut Porter (1985), kegiatan utama dalam rantai nilai adalah: 1) Logistik inbound (hubungan dengan pemasok, mencakup semua aktivitas yang dibutuhkan untuk menerima, menyimpan, dan menyebarkan masukan), 2) Operasi (kegiatan untuk mengubah input menjadi output (produk dan layanan), 3) Logistik outbound (semua kegiatan untuk mengumpulkan, menyimpan, dan mendistribusikan hasilnya, 4) Pemasaran dan Penjualan (kegiatan menginformasikan pembeli tentang produk dan layanan, mendorong pembeli untuk membelinya, dan memfasilitasi pembelian mereka), dan 5) Layanan (aktivitas untuk menjaga agar produk atau layanan bekerja secara efektif bagi pembeli setelah dijual dan dikirim).

Sedangkan kegiatan sekunder dalam rantai nilai adalah: 1) Pengadaan (perolehan input atau sumber daya), 2) Manajemen Sumber Daya Manusia (perekrutan, seleksi, pelatihan, pengembangan, kompensasi dan (jika perlu) menolak atau memberhentikan personil), 3) Pengembangan Teknologi (peralatan, perangkat keras, perangkat lunak, prosedur dan pengetahuan teknis yang dibawa ke dalam transformasi input perusahaan menjadi keluaran, dan 4) Infrastruktur untuk melayani kebutuhan perusahaan, terdiri dari fungsi departemen seperti akuntansi, hukum, keuangan, perencanaan, urusan publik, hubungan pemerintah, penjaminan mutu dan manajemen umum (Mete dan Acuner, 2014). Ide keunggulan kompetitif suatu kegiatan usaha dirangkum dalam ilustrasi Gambar 3.1.

\section{Gambar 1. Rantai Nilai Porter}

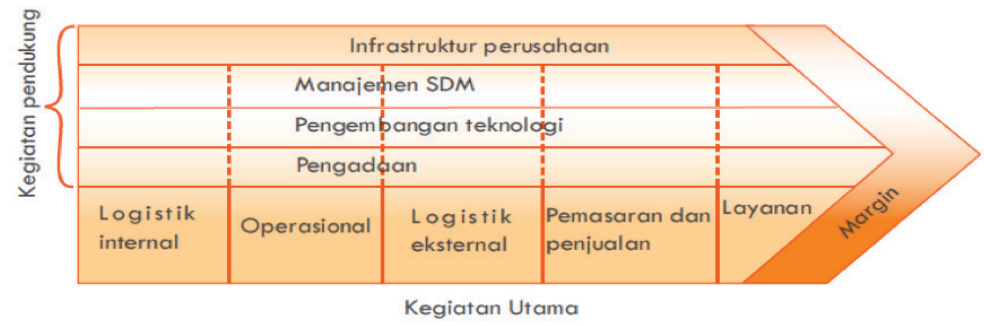




\section{Metode Kajian}

Kajian menggunakan pendekatan kualitatif untuk menghasilkan gambaran yang kaya, detail, dan lengkap mengenai suatu fenomena yang diteliti (R.K. Yin, 1994). Pendekatan penelitian kualitatif melibatkan serangkaian langkah-langkah iterasi, mulai dari proses perumusan pertanyaan penelitian, penentuan metode penelitian, pengumpulan dan analisis data sampai penarikan kesimpulan (Elgie, et al., 2010). Desain penelitian menggunakan metode deskriptif dengan melakukan wawancara mendalam dan Focus Group Discussion (FGD) untuk memperoleh data dan informasi primer yang lebih mendalam. Adapun data sekunder diperoleh dari kajian desk study (studi pustaka), berupa laporan-laporan studi terdahulu, paper, makalah, dan dokumen kinerja pemerintahan yang relevan.

Data yang terkumpul kemudian dianalisis sehingga ditemukan variabel dan indikator yang dapat mempengaruhi kinerja pengembangan daya saing wisata di Pulau Nikoi. Setelah menganalisis faktor-faktor internal dan eksternal dalam rantai nilai pariwisata di Kepualauan Seribu, kemudian dianalisis lebih lanjut berdasarkan model Rantai Nilai Porter (1985). Hasil dan analisa yang diperoleh dari wawancara mendalam, FGD, maupun olahan data sekunder divalidasi melalui dua kali workshop atau FGD lanjutan sebelum menjadi rekomendasi akhir kajian. Penelitian dilaksanakan di Pulau Nikoi, Kabupaten Bintan, Propinsi Kepulauan Riau pada 2017. Alasan pemilihan Pulau Nikoi adalah mewakili contoh praktik wisata bahari Pulau-Pulau Kecil yang tidak berpenghuni dan dikelola sepenuhnya oleh sektor swasta.

\section{Hasil dan Analisa}

\subsection{Profil Pulau Nikoi, Kabupaten Bintan, Propinsi Kepulauan Riau}

Pulau Nikoi adalah sebuah pulau pribadi, berjarak lima kilometer dari pantai timur Pulau Bintan di wilayah perairan Laut Cina Selatan. Beberapa pulau kecil lain yang telah ditetapkan dan menjadi prioritas pengembangan wisata bahari di sekitar Pulau Bintan antara lain Pulau Magpur, Pulau Sulung, dan Pulau Telang. Aksesabilitas dari Pulau Bintan hanya setengah jam. Sejalan dengan peningkatan peran sektor pariwisata dalam menunjang PAD, Pemerintah Kabupaten Bintan mulai mengembangkan pulau-pulau kecil di gugusan Kepulauan Tambelang yang berada di perairan Laut Cina Selatan, berbatasan dengan Propinsi Kalimantan Barat. Untuk mencapai gugusan kepulauan tersebut memerlukan waktu sekitar 20 jam bila ditempuh dengan kapal laut dari Bintan atau sekitar tujuh jam dari Kalimantan Barat.

Memiliki akses yang hanya memerlukan waktu sekitar satu jam dari Pulau Bintan dan dekat dengan Singapura, merupakan kunci utama keberhasilan mengembangkan pulau eksotik ini. Pulau Nikoi telah berkembang menjadi tujuan wisata alam yang popular dengan segmen keluarga dan kegiatan korporat. Seluruh resort yang ada umumnya sudah dipesan penuh pada akhir pekan berbulan-bulan sebelumnya, membuktikan reputasi Pulau Nikoi cukup baik. Pada 2009 pemilik Nikoi membentuk The Island Foundation untuk membantu masyarakat setempat berkembang secara berkelanjutan dan telah terdaftar sebagai badan amal Internasional di Singapura pada 2010. Untuk memenuhi pasar turis untuk kegiatan honey moon, grup investor telah dan sedang mengembangan pulau baru di Pulau Cempedak yang juga berada di kawasan Kabupaten Bintan. 


\subsection{Faktor Pendorong Pengembangan Daya Saing Pulau Nikoi sebagai Daerah Tujuan Wisata} Bahari

Berdasarkan hasil wawancara mendalam, Focus Group Discussion (FGD), dan kajian pustaka, faktor-faktor pendorong yang dapat mempengaruhi pengembangan daya saing Pulau Nikoi sebagai daerah tujuan wisata bahari di Kabupaten Bintan dijelaskan lebih rinci sebagai berikut.

\subsubsection{Kekayaan dan Keunikan Sumberdaya}

Keunikan dan kekayaan sumberdaya alam yang dimiliki Pulau Nikoi merupakan modal dasar sebagai tujuan wisata bahari untuk menarik wisatawan dari seluruh dunia. Sebagian besar pulau masih ditutupi hutan tropis. Sementara pantai berpasir putih bersih mengelilingi sebagian pulau. Beriklim tropik dengan angin sepoi-sepoi yang sejuk dengan suhu di antara 26 derajat celcius sampai 32 derajat celcius, cocok untuk turis yang ingin menikmati olahraga berlayar dengan memanfaatkan tenaga angin (yacht). Pulau Nikoi memiliki beberapa spot ekosistem terumbu karang terbaik di daerah ini yang dapat dijadikan objek snorkling. Pengunjung juga bisa melihat keberadaan penyu sisik termasuk menyaksikan anak-anak penyu yang mulai menetas dan bergerak ke arah pantai (pada musim yang tepat). Kegiatan menerbangkan layang layang juga dapat dilaksanakan di Pulau ini. Di tengah-tengah hutan dan sudut-sudut pantai, batu granit ukuran raksasa bertebaran mempercantik bentang alam pulau ini.

\subsubsection{Perencanaan Strategis}

Perkembangan Pulau Nikoi tidak lepas dari dukungan Pemerintah Daerah yang telah menjadikan pariwisata sebagai sektor prioritas daerah dengan mengesahkan Peraturan Daerah Tentang Rencana Induk Pembangunan Pariwisata Daerah (RIPDA) sebagai dokumen payung hukum untuk Perencanaan Pembangunan Pariwisata Daerah Kabupaten Bintan. Rencana induk tersebut kemudian diterjemahkan dalam bentuk Rencana Strategis Dinas Pariwisata dan Kebudayaan Kab. Bintan, yang telah menyusun sejumlah kebijakan/program dalam upaya meningkatkan Pendapatan Asli Daerah. Untuk tahun 2015 misalnya, ada tiga Kebijakan/Program yaitu: a. Program Pengembangan Pemasaran Pariwisata, b. Program Pengembangan Destinasi Pariwisata, dan c. Program Pengembangan SDM Kebudayaan dan Pariwisata.

Dari sudut pandang korporat, pengelola Pulau Nikoi memiliki perencanaan strategis yang diterjemahkan dalam bentuk rencana bisnis tiap tahunan. Rencana bisnis tiap tahunan tersebut tentu saja mengikuti rencana fundamental pengembangan bisnis Pulau Nikoi sebagai satu entitas wisata bahari yang unik, yaitu tujuan liburan dengan menonjolkan kekayaan ekologis dan keindahan alam yang dimiliki pulau tersebut dengan segmen pasar keluarga dan korporate untuk aktivitas team building.

\subsubsection{Kepastian Rencana Tata Ruang dan Wilayah}

Pemerintah Kabupaten Bintan telah merencanakan pemanfaatan pulau-pulau kecil, seperti Pulau Nikoi, dan sebagainya untuk dikembangkan menjadi salah satu tujuan wisata bahari dan telah mengesahkan Perda Tata Ruang sejak 2012 yang akan berlaku sampai 2017. Pemda telah menerima masukan dari berbagai pihak sehingga melakukan revisi 
untuk mengatasi persengketaan yang terjadi di lapangan menyusul adanya persengketaan kepentingan antar pihak. Revisi Perda yang mengatur Rencana Tata Ruang dan Wilayah tersebut direncanakan akan selesai dan segera disahkan pada 2018.

Selain itu, untuk kawasan perairan, menyusul kewenangan perairan dari Kabupaten/ Kota (0-4 mil dari pantai) yang ditarik ke Propinsi menjadi 0-12 mil dari pantai, Pemerintah Kabupaten Bintan telah berkoordinasi dengan Pemerintah Propinsi Kepulauan Riau untuk menentukan zonasi di wilayah perairan. Sejumlah pulau-pulau kecil yang merupakan objek wisata bahari telah masuk dalam zona inti yang dijaga kelestarian lingkungannya. Dengan selesainya peta zonasi tersebut (yang ditargetkan selesai pada 2018), maka seluruh aturan pemanfaaatan PPK dan ruang laut, itu harus sesuai berdasarkan zonasi itu.

\subsubsection{Kemudahan Berusaha}

Pemerintah daerah memberikan perijinan sesuai dengan peraturan yang berlaku sesuai perundang-undangan dan peraturan lainnya, misalnya aturan rinci dari Peraturan Meteri. Selama persyaratan dan prosedur perijinan dipenuhi oleh investor, petugas di pelayanan perijinan satu pintu akan mengeluarkan ijin yang diminta. Untuk pengurusan prospek investasi pengembangan wisata di pulau pulau kecil di Kabupaten Bintan, jika tahapan dan persyaratan dipenuhi investor ditargetkan bisa selesai dalam tiga bulan.

Sejumlah permasalahan terkait aspek perijinan disebabkan karena investor atau swasta, dalam beberapa tahap proses pengajuan perijinan itu tidak runut dalam prosesnya. Investor umumnya telah melaksanakan pembeliaan lahan lebih dulu baru kemudian mengurus ijin ke PTSP. Hal ini lah yang membuat hambatan karena pengelola ijin biasanya tidak bersedia mengeluarkan ijin yang diminta karena khawatir akan melanggar perundangundangan dan peraturan hukum yang ada.

\subsubsection{Pengembangan Produk Wisata bahari}

Kebijakan Pemerintah Daerah Kabupaten Bintan dalam mengembangkan pariwisata di Kabupaten Bintan adalah menonjolkan keindahan dan keanekaragaman kekayaan sumberdaya alam yang ada di daerah ini dengan didukung penerapan budaya Melayu yang menitikberatkan nilai-nilai agama Islam. Prinsip tersebut sesuai dengan konsep dasar pengembangan wisata bahari yang menonjolkan kekayaaan ekosistem bahari baik berupa keindahan pantai maupun pulau-pulau kecil. Untuk menunjang wisata bahari bahari maka Pemerintah Daerah mendorong melalui berbagai kegiatan olahraga dan petualangan dan cenderung membatasi kegiatan wisata yang bersifat hiburan malam atau kegiatan-kegiatan lain yang bertentangan dengan budaya Melayu.

Kebijakan Pemerintah Daerah Kabupaten Bintan tersebut sesuai dengan sudut pandang korporat. Pengelola Pulau Nikoi mengembangkan pulau untuk tujuan wisata bahari dengan menonjolkan kekayaan ekologis dan keindahan alam yang dimiliki pulau tersebut. Turis dapat bertelanjang kaki sederhana di hamparan pantai berpasir putih. Selain keindahan dan keanekaragaman alam dan pengelola resor juga menawarkan berbagai aktivitas petualangan seperti berjemur, berenang, snorkling, diving, berlayar, dan olah raga panjat tebing. Selain resort dengan arsitektur yang menggunakan bahan kayu tropis, juga dilengkapi kolam renang, sarana olah raga dan lounge. Pulau Nikoi menawarkan lingkungan alami dan aman bagi keluarga dan anak-anak untuk bebas berimajinasi tanpa batas. 


\subsubsection{Pengembangan SDM Pariwisata}

Pemerintah Kabupaten Bintan, melalui jajarannya di Dinas Pariwisata telah melaksanakan berbagai pelatihan SDM pariwisata misalnya pelatihan diving dan snorkling. Untuk jalur formal, pemerintah mendorong pengembangan SMK Pariwisata dan akademi pariwisata yang bekerjasama dengan Universitas Sahid.

\subsubsection{Pengembangan dan Dukungan UMKM}

Pemerintah Kabupaten Bintan telah mengembangkan pelatihan dan pendampingan manajemen pengelolaan kegiatan pariwisata untuk masyarakat desa mengelola potensi wisata di kawasannya. Mereka dihimpun dalam Badan Usaha Milik Desa melalui dana alokasi dana desa, satu desa mendapat dana sekitar Rp 2 milyar dimana lembaga pengelolanya diserahkan ke masyarakat desa. Contoh dari kegiatan pariwisata yang dikelola Badan Usaha Milik Desa adalah pengelola rumah penginapan terapung (kelong), pengembangan wisata di desa mangrove atau desa gurun sahara (bekas galian pertambangan) .

Sejalan dengan kebijakan Pemerintah Kabupaten, pengelola Pulau Nikoi telah menjalin kerjasama dengan para pemangku kepentingan relevan, utamanya masyarakat lokal untuk mendorong prospek bisnis di Pulau tersebut. Dukungan kerjasama dengan masyarakat lokal antara lain berupa dukungan logistik dengan bahan bahan pangan lokal maupun merancang berbagai kegiatan sosial seperti memberikan kursus bahasa Inggris dan komputer untuk para remaja di sekitar lokasi usaha. Sebuah merek ritel sedang dibangun yang akan digunakan untuk membantu penduduk desa menjual karya seni dan kerajinan yang telah dibantu dikembangkan. Ke depan, upaya ini diharapkan dapat membantu warga desa membangun bisnis yang akan membantu mengurangi ketergantungan mereka pada industri perikanan yang mengalami penurunan.

\subsubsection{Pengembangan Pemasaran}

Pemerintah Kabupaten Bintan telah merancanag strategi pemasaran Pulau Bintan dengan melaksanakan sejumlah even-even olah raga skala internasional, antara lain balap sepeda, olah raga air dan marathon. Kebijakan pemda memang mendorong pada sport tourism dan tourism petualangan melalui wisata. Juga mendorong pameran-pameran. Pengelola Pulau Nikoi telah merencanakan dan menjalankan strategi pemasaran korporat dengan menjalin kerjasama dengan berbagai perusahaan tour and travel di seluruh dunia, khususnya di Singapura.

\subsubsection{Pengembangan Komunikasi Teknologi Informasi (ITC)}

Untuk mengembangkan pasar, pengelola Pulau Nikoi telah membangun dan mengembangkan websites termasuk dilengkapi fasilitas pemesanan online. Selain itu juga berkerjasama dengan agen tour and travel internasional Asia Travel di Singapura.

\subsubsection{Infrastruktur}

Pemerintah daerah Kabupaten Bintan mendorong perkembangan pariwisata melalui pembangunan infrastruktur di sekitar objek wisata, antara lain pembangunan jalan dan jembatan. Juga ada Bandara dan jalur penyeberangan feri. Sarana dan prasarana untuk melengkapi aspek fasilitas sosial (sarana kesehatan, komunikasi, kemanan dan pengelolaan 
limbah) juga dilaksanakan Pemda sesuai tanggungjawab mereka untuk memenuhi layanan ke masyarakat. Pembangunan sarana dan prasarana tersebut tentu dapat dimanfaatkan untuk kepentingan pariwisata.

Untuk lokasi yang menjadi domain pengelola Pulau Nikoi, investor membangun semua prasarana dan sarana yang diperlukan. Termasuk dermaga penyeberangan dan tempat kapal yang melayani rute demaga milik perusahaan dengan Pulau Nikoi. Praktik wisata (kegiatan pariwisata berbasiskan pengelolaan lingkungan yang baik) diimplementasikan dengan memperhatikan konservasi dan pertimbangan isu lingkungan. Pengelola tidak memberi label Nikoi sebagai "resort eko" karena tidak ingin terjebak menjadi sekadar jargon tanpa makna. Praktik eco resort sebaliknya diimplementasikan inheren dalam pengelolaan sehari-hari yang tampak dari konsep pengembangan resort (akomodasi), pengelolaan air tanah, efisiensi energi dengan memanfaatkan energi matahari (solar cell), pengembangan lanskap yang dibiarkan senatural mungkin, manajemen persampahan dan pengelolaan limbah B3, dan bahkan memiliki sistem pengendalian nyamuk.

\subsubsection{Faktor Keamanan}

Aspek keamaan merupakan faktor kondisi yang harus diciptakan agar turis dapat menikmati berbagai kegiatan wisata bahari yang ditawarkan dengan nyaman. Penciptaan keamanan ini sejalah dengan tugas dan fungsi aparat pemerintah daerah dan kepolisian setempat dalam menjalankan tugasnya. Dari sisi investor, aspek keamanan juga berkaitan dengan kelangsungsan dan ketenangan dalam menjalankan usaha sehari-hari yang kerapkali mendapatkan ancaman atau intimidasi dari sejumlah pihak terkait persengketaan sumberdaya yang ada. Untuk mengatasi hal tersebut, strategi yang dijalankan investor adalah memperkuat jejaring (partnership) dalam membangun dan mengembangkan kerjasama dan kolaborasi dengan Pemda dan masyarakat lokal sehingga dapat menguragi potensi konflik yang dapat merugikan usaha wisata.

\subsection{Analisis Rantai Nilai Pengembangan Pulau Nikoi sebagai Daerah Tujuan Wisata bahari}

Hasil identifikasi sejumlah faktor pendorong pengembangan daya saing wisata bahari di Pulau Nikoi Kabupaten Bintan selanjutnya dianalisis berdasarkan konsep rantai nilai daya saing Michael Porter. Model rantai nilai tersebut dapat menjadi model untuk pengembangan Pulau-Pulau Kecil yang dikelola oleh sektor swasta atau konsorsium swasta. Berkembangnya Pulau Nikoi dan Kabupaten Bintan umumnya sebagai daerah tujuan wisata bahari yang berdaya saing, pertama-tama karena adanya faktor kondisi sebagai modal dasar, yiatu adanya kekayaan dan keunikan sumberdaya alam yang dapat menawarkan keindahan dan pengalaman bagi para pelancong (Lihat Gambar. 2).

Model rantai nilai tersebut menujukkan peran investor Pulau Nikoi sepenuhnya mengendalikan usaha wisata di Pulau Nikoi. Investor selaku pengelola Pulau berperan sentral mulai dari perencanaan, desain konstruksi pembangunan sampai pengelolaan bisnis sehari-hari termasuk terus menerus untuk melaksanakan perbaikan di setiap aspek agar dapat memenuhi kebutuhan pasar (selera konsumen) yang terus berubah.

Di sisi lain, Pemerintah Daerah berkontribusi penting dalam menciptakaan kondisi lingkungan bisnis yang kondusif untuk berlangsungnya wisata bahari yang menguntungkan. Sesuai dengan tugas dan fungsinya, pemerintah daerah berperan penting dalam memberikan 
rasa aman terkait aspek kepastian usaha, yaitu: adanya perencanaan stratagis pembangunan wisata termasuk kepastian rencana tata ruang dan tata wilayah) dan aspek kemudahan berusaha (aspek perijinan). Pemerintah daerah juga diharapkan memiliki starategi untuk mendorong pariwisata daerah, yaitu: aspek pengembangan produk pariwisata, SDM Pariwisata, dukungan UMKM, dukungan pemasaran kawasan, dukungan infrastruktur, fasilitas Komunikasi Teknologi Informasi (ITC), dan jaminan keamanaan.

Gambar 2. Pola rantai nilai wisata bahari di Pulau Nikoi, Kabupaten Bintan, Propinsi Kepulauan Riau

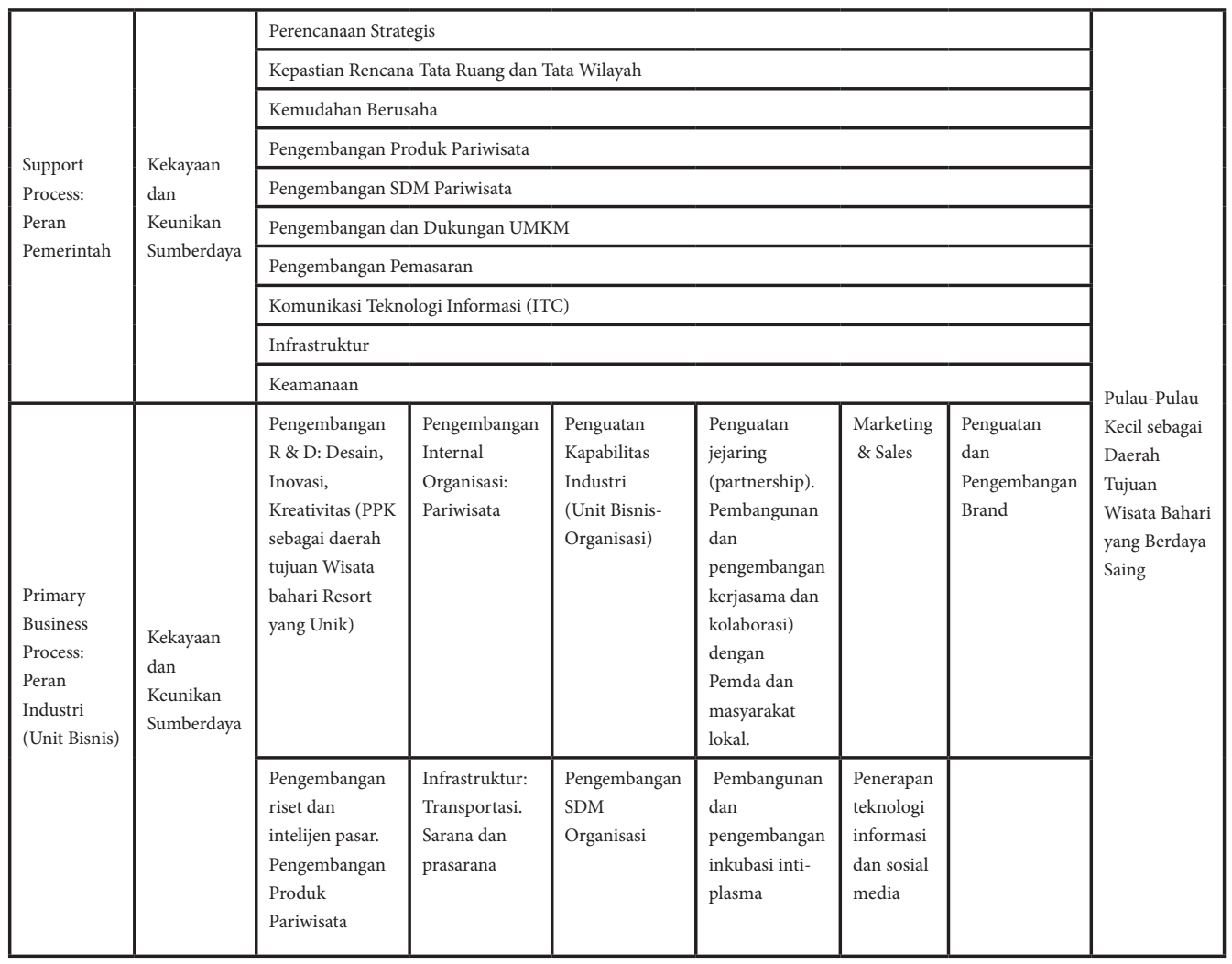

Sumber: Kajian Peneliti (2017)

\section{Penutup}

\subsection{Kesimpulan}

Faktor kondisi sebagai modal dasar pengembangan wisata bahari di Pulau Nikoi adalah adanya kekayaan dan keunikan sumberdaya alam yang dapat menawarkan keindahan dan pengalaman bagi para pelancong. Investor selaku pengelola Pulau berperan sentral mulai dari perencanaan, desain konstruksi pembangunan sampai pengelolaan bisnis termasuk terus menerus untuk memperbaiki setiap aspek proses bisnis untuk memenuhi perubahan dinamis kebutuhan pasar (selera konsumen).

Kontribusi Pemerintah Daerah Kabupaten Bintan penting untuk menciptakan lingkungan bisnis di kawasan Kabupaten Bintan kondusif untuk perkembangan wisata bahari. Sesuai dengan tugas dan fungsinya, pemerintah daerah diharapkan dapat berkontribusi dalam memberikan rasa aman terkait aspek kepastian usaha. Itu dapat didukung melalui adanya perencanaan stratagis pembangunan wisata termasuk kepastian rencana tata ruang 
dan tata wilayah dan aspek kemudahan berusaha, utamanya kejelasan aspek perijinan usaha. Pemerintah daerah juga diharapkan memiliki starategi untuk mendorong daya saing pariwisata kawasan melalui pengembangan produk pariwisata, peningkatan kualitas SDM Pariwisata, dukungan ke UMKM, dukungan pemasaran kawasan, dukungan infrastruktur, fasilitas Komunikasi Teknologi Informasi (ITC), dan jaminan keamanaan.

\subsection{Saran}

Pengembangan Pulau Nikoi di Kabupaten Bintan dapat dijadikan model pengembangan wisata bahari PPK dengan pelaku dominan dari investor swasta. Kendati demikian, dalam implementasi di lapangan, peran swasta tidak bisa berdiri sendiri namun harus mampu bekerjasama dengan Pemerintah (baik di tingkat Pusat dan Dearah) maupun para pemangku kepentingan terkait dari sektor masyarakat. Kerjasama antar pelaku usaha dalam konteks penguatan rantai nilai pengembangan usaha wisata bahari PPK menjadi hal penting. Beberapa aspek penting yang dapat dijadikan fokus kerjasama antara lain: a) Penanganan sampah, limbah, dan bahan beracun berbahaya (B3), b) Pengembangan pemberdayaan UMKM berbasis bisnis atau usaha ekowisata PPK, c) Pelestarian lingkungan hidup, berhubungan dengan sejumlah isu penting: air bersih, energi, dan kelestarian flora, fauna, dan ekosistem, d) Dan lain-lain.

\section{Daftar Referensi}

Bappenas. (2014). Kebijakan dan Strategi Pengelolaan Pulau-pulau Kecil. http://www. bappenas.go.id/index.php/download file/view/11618/3863/. Diunduh pada 18 Maret 2014.

BPPPD Kabupaten Bintan. (2017). Ekspose Kepala BPPPD Kabupaten Bintan. Tim Kajian Kebijakan Kerjasama Pembangunan Pariwisata di Pulau-Pulau Kecil

Cetinski, Vinka., and Ines Milohnic. (2008). Company Competitiveness and Competitive Advantages in Tourism and Hospitality. Tourism and Hospitality Management, Vol. 14, No. 1 .

Croes, Robertico. (2010). Small Island Tourism Competitiveness: Expanding Your Destination"s Slice of Paradise. Invited Main Lecture at the occasion of the Dies Natalis of the University of the Netherlands Antilles, Willemstad, Curacao, January 12, 2010.

Dahuri R. (1998). Pendekatan Ekonomi-Ekologis Pembangunan Pulau-Pulau Kecil Berkelanjutan. Prosiding Seminar dan Lokakarya Pengelolaan Pulau-Pulau Kecil di Indonesia. Jakarta: Dit. Pengelolaan Sumberdaya Lahan dan Kawasan, TPSA BPPT, CRMP USAID.

Elgie, Susan., Ruth Childs, Nancy E. Fenton, Betty Ann Levy, Valerie Lopes,Karen Szala-

Meneok, and Richard Dominic Wiggers. (2010). Researching Teaching and Student

Outcomes in Postsecondary Education: A Guide.Toronto: The Higher Education Quality

Council.

Henry Tsai , Haiyan Song \& Kevin K. F. Wong. (2009). Tourism and Hotel Competitiveness

Research. Journal of Travel \& Tourism Marketing. 26:5-6, 522-546.

Kaplinsky, R. and M. Morris. 2001. A Handbook for Value Chain Research. Brighton, United

Kingdom, Institute of Development Studies, University of Sussex.

Kemenpar. 2015. Laporan Naskah Akademik Strategi Pengembangan Kawasan Pesisir dan 


\section{Pulau-Pulau Kecil.}

Kementerian Pariwisata. (2017). Neraca Satelit Pariwisata Nasional 2016. http://kemenpar. go.id.

Kementerian Pariwisata. (2017). Perkembangan Bulanan Wisatawan Mancanegara, 2010 2016. http://kemenpar.go.id.

Kementerian Pariwisata. (2016). Statistik Profil Wisatawan Mancanegara 2016. Asisten Deputi Penelitian dan Pengembangan Kebijakan Kepariwisataan. Deputi Bidang Pengembangan Kelembagaan Kepariwisataan. Kementerian Pariwisata

McElroy, Jerome L. Managing Sustainable Tourism in the Small Island Caribbean. the Journal of Ecological Economics. September 2000.

Mete, Bilgen., and Elif Acuner. (2014). A Value Chain Analysis of Turkish Tourism Sector. International Journal of Business and Management Studies, CD-ROM. ISSN: 21581479: 03(02):499-506 (2014).

Muf. (2015). Wow! Pariwisata Bintan Dulang Rp 92,79 M. Batam Pos. Diakses dari https:// arsip.batampos.co.id/12-12-2015/wow-pariwisata-bintan-dulang-rp-9279-m/.

Porter, Michael E. (1985). Competitive Advantage.The Free Press. New York. 1985.

\section{Situs Web:}

www.nikoi.com

UNWTOb.2016. Tourism Highlights: 2016 Edition. mkt.unwto.org 